\title{
Identification of Sex from Foramen Magnum of Egyptian Skulls Using Three Dimensional Computed Tomography
}

\section{Ragaa T Darwish, Nagla M Salama', Mohamed N Elsirafy ${ }^{2}$, and Wael S Kholeif ${ }^{1}$}

\author{
${ }^{1}$ Forensic Medicine and Clinical Toxicology Department \\ ${ }^{2}$ Radiodiagnosis Department
}

Faculty of Medicine, Alexandria University, Alexandria, Egypt

\begin{abstract}
Sex determination from skeletons is an important research subject in forensic medicine. This study aimed to evaluate the sexual dimorphism in the Egyptian skulls based on foramen magnum and some cranial measurements.

Methodology: The present study was performed on 100 adult Egyptian patients of both sexes. Multi- Slice Computerized Tomography (MSCT) scan were obtained and reconstruction of 3D models for the cranium was performed. Various parameters related to the foramen magnum, the right condyle and the left condyle were measured on virtual skulls of adult patients.

Results: The mean length, width and area of foramen magnum were significantly higher in males( $35.3 \pm$ $1.9 \mathrm{~mm}, 30.0 \pm 1.9 \mathrm{~mm}$ and $833.50 \pm 72.52 \mathrm{~mm}^{2}$ respectively) than in females $(32.8 \pm 2.5 \mathrm{~mm}, 27.1 \pm 2.4 \mathrm{~mm}$ and $699.90 \pm 92.09 \mathrm{~mm}^{2}$ respectively). The mean lengths of the maximum bicondylar distance, minimum intercondylar distance and maximum medial intercondylar distance were significantly longer in males $(48.8$ $\pm 2.3,17.2 \pm 1.7$ and $25.1 \pm 2.4 \mathrm{~mm}$ respectively) than in females $(46.1 \pm 2.2,16.2 \pm 1.8$ and $22.7 \pm 1.7 \mathrm{~mm}$ respectively ). A significant difference between males and females was elicited regarding the length (24.8 \pm 1.7 and $22.7 \pm 2.2 \mathrm{~mm}$ respectively) and the width ( $14.4 \pm 1.3$ and $13.5 \pm 1.3 \mathrm{~mm}$ respectively) of the right condyle. The equation which determines sex with high accuracy was the one made from the length of the foramen magnum, length of the right condyle and length of the left condyle, the accuracy reached $87 \%$.

Conclusion: It can be concluded that measurements of the foramen magnum and the condyles obtained using 3D CT and the equations acquired from them are reliable tools in sex determination.
\end{abstract}

Keywords Sex Identification, Foramen Magnum, Occipital Condyle

\section{Introduction}

$\mathrm{O}$ ne of the crucial aims of a medicolegal investigation is to establish the identity of a deceased, especially in cases where skeletal remains and dismembered or mutilated body parts are recovered and brought for examination. When confronted with one of the previously mentioned cases, often the first question the forensic anthropologist faces is who is the decedent? To determine the answer, it is vital to estimate the "big four": age, sex, stature and race in order to establish the biological profile of the remains (Calcagno JM, 1981).

Sex is the first demographic factor that is determined because it reduces the number of possible matches by $50 \%$ (Cardoso and Saunders, 2008).
Various parts of a skeleton are useful in sex determination. Human skull is considered as one of the most reliable bones for sex differentiation (Kanchan et al., 2013).

During severe disruptive injuries, estimation of sex becomes challenging when only a part of skull is brought for examination and hence, a need to derive standards for sex estimation from different regions of the skull. The basal region of the occipital bone is more likely to survive physical insults than the other parts of the skull owing to the abundant soft tissue cover, skull thickness in the region, and its relatively well-protected anatomical position. Thus, there is an increased possibility of recovering this part of skull even in cases 
of severe trauma, and studies on the occipital bone may provide useful clues in identification of significantly disrupted remains (Gapert et al., 2009).

Medical imaging modalities, like CT, provide unique data sources for examining modern human variation in a more quantitative manner when extending osteological resources to researchers beyond actual contact (Weber et al., 1998).

Using the newest technology of Multi Slice CT (MSCT) makes it possible to form images that are very similar to the original bone shape that needs to be measured, in any axis and in a rapid manner (Verhoff et al., 2008).

The foramen magnum is an important landmark of the skull base and is of particular interest for anthropology and forensic medicine. The sex discriminant value of the foramen magnum has always attracted the attention of researchers who stressed its value in sex discrimination. The ability to construct a biological profile from metric analysis on virtual skeletons and the ability to develop formulas from these measurements will help to solve many medicolegal problems. The present study aimed at establishing the accuracy and the reliability of the foramen magnum and some cranial measurements in sex determination using three dimensional computed tomography (3D CT).

\section{Subjects and Methods}

The present study was performed on 100 adult Egyptian patients of both sexes from Lower Egypt. All patients were chosen randomly when referred to the RadioDiagnosis Department of Alexandria Main University Hospital for radiological investigations by Multi- Slice Computerized Tomography (MSCT) of the skull. Prior permission was sought from Head of Radiology Department and an informed consent was obtained from all patients before participation in the present study. Patients with skeletal deformities, degenerative alterations, traumatic or pathological lesions of head that could preclude accurate measurements were excluded.

For each case, the MSCT scan was obtained and reconstruction of high quality $3 \mathrm{D}$ models for the cranium was performed. Various parameters related to the foramen magnum and both the right and the left condyles were measured on virtual skulls of the adult patients.

The metric parameters (in $\mathrm{mm}$ ) were as follows:

\section{A-Measurements of the foramen magnum and the inter condylar distance (Figure 1) (Uysal et al., 2005)}

- Length of the foramen magnum (LFM): The maximum internal length of the foramen magnum along the mid sagittal plane.
- Width of the foramen magnum (WFM): The maximum internal width of the foramen magnum perpendicular to the mid-sagittal plane.

- Foramen magnum index (FMI) (Sangvichien et al., 2007): It was calculated by dividing the length of the foramen magnum by the width of the foramen magnum.

- Foramen magnum area (FMA) (Gunay et al., 1997): It was calculated using the Radinsky's formula: FMA (in $\mathrm{mm} 2$ ) $=0.25 \times \mathrm{L} \times \mathrm{W} \times 22 / 7 \mathrm{~L}=$ length of the foramen magnum. $\mathrm{W}=$ width of the foramen magnum.

- Maximum bicondylar distance (MBD): The maximum distance between the lateral edges of the articular surfaces of the condyles. It is also known as the bicondylar breadth.

- Maximum medial intercondylar distance (MID): The maximum distance between the medial articular margins of the condyles. It is also known as the intercondyler breadth.

- Minimum intercondylar distance (MnID): The minimum distance between the medial edges of the articular surfaces of the condyles.

\section{B- Measurements of the occipital condyles (Figure 2) (Uysal et al., 2005)}

- Length of right condyle (LRC): The maximum length of right condyle along the long axis from the edges of the articular surface.

- Width of right condyle (WRC): The maximum width of right condyle from the articular edges along a line perpendicular to the long axis.

- Length of left condyle (LLC): The maximum length of left condyle along the long axis from the edges of the articular surface.

- Width of left condyle (WLC): The maximum width of left condyle from the articular edges along a line perpendicular to the long axis.

- Condylar index (CI). It was calculated by dividing the length of the occipital condyle by the width of the occipital condyle .It was calculated for the right and the left occipital condyles (RCI and LCI respectively).

The data collected were fed to the computer and analyzed using IBM SPSS software package version 20.0. Quantitative data were described using mean and standard deviation, median, minimum and maximum. The distribution of quantitative variables was tested for normality using Kolmogorov-Smirnov test, Shapiro-Wilk test and D'Agstino test. Histogram and QQ plot were also used for vision test (Leslie and Geoffrey, 1991; Kirkpatrick and Feeney, 2013). 


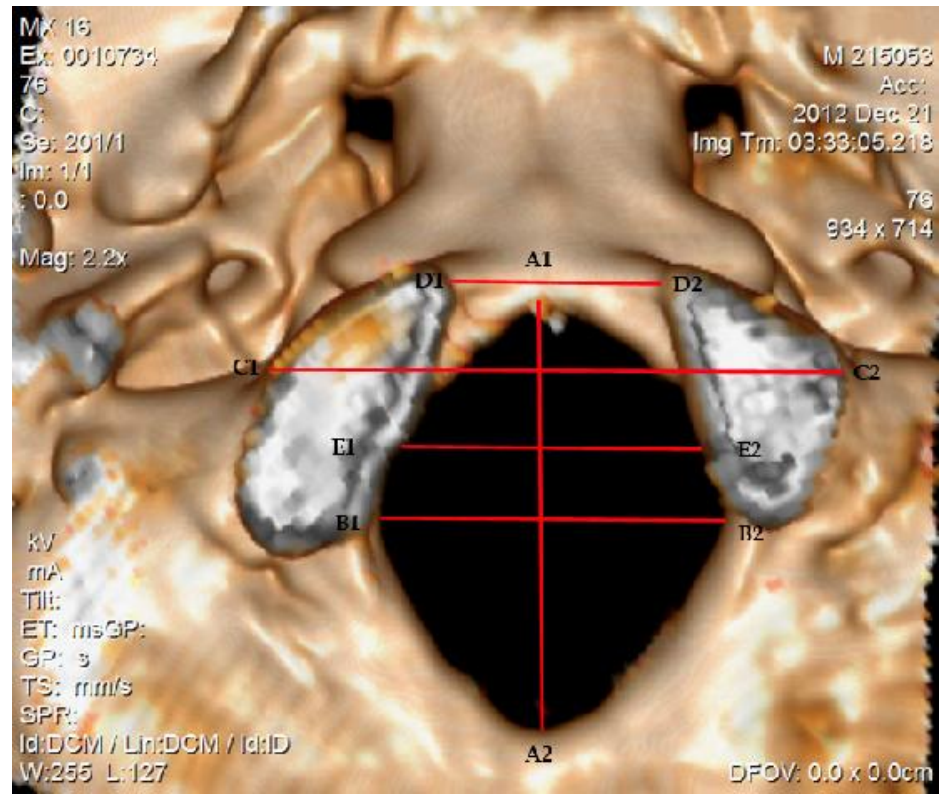

Figure 1: 3DMSCT of the base of the skull showing the different measurements (in mm) for the foramen magnum and the inter condylar distance.

$A_{1}-A_{2}(L F M)=$ the maximum internal length of the foramen magnum along the mid sagittal plane.

$B_{1}-B_{2}(W F M)=$ the maximum internal width of the foramen magnum perpendicular to the midsagittal plane.

$\mathrm{C}_{1}-\mathrm{C}_{2}(\mathrm{MBD})=$ the maximum distance between the lateral edges of the articular surfaces of the condyles.

$D_{1}-D_{2}(M n I D)=$ the minimum distance between the medial edges of the articular surfaces of the condyles

$\mathrm{E}_{1}-\mathrm{E}_{2}(\mathrm{MID})=$ the maximum distance between the medial articular margins of the condyles

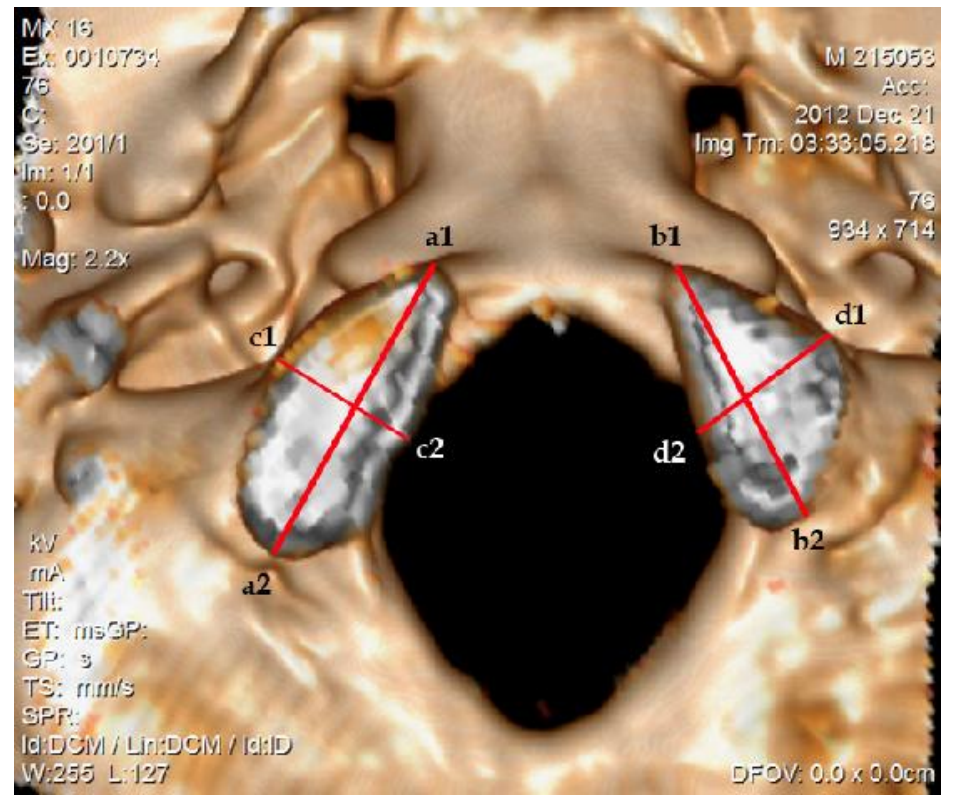

Figure 2: 3DMSCT of the base of the skull showing the different measurements (in mm) for the right and left occipital condyles.

$a_{1}-a_{2}(L R C)=$ the maximum length of right condyle along the long axis from the edges of the articular surface.

$b_{1}-b_{2}(L L C)=$ the maximum length of left condyle along the long axis from the edges of the articular surface.

$c_{1}-c_{2}(W R C)=$ the maximum width of right condyle from the articular edges along a line perpendicular to the long axis.

$\mathbf{d}_{1}-\mathbf{d}_{2}(\mathrm{WLC})=$ the maximum width of left condyle from the articular edges along a line perpendicular to the long axis

\section{Results}

Table (1) shows the age distribution of male\& female patients. In males, it ranged from 19-56 years with a mean age of $31.58 \pm 9.03$ years while in female sit ranged from 18- 60 years with a mean age of $40.93 \pm$ 
13.40 years. There was significant difference as regard age between both sexes, where $p \leq 0.001$. Forty percent of the patients were in age group ranging from 18-30 years.

Comparative statistics with the maximum and minimum values, means and standard deviations for the length and the width of the foramen magnum in both males and females are presented in Table (2). The table reveals that the mean length of the foramen magnum was significantly longer in males $(35.3 \pm 1.9 \mathrm{~mm})$ than in females $(32.8 \pm 2.5 \mathrm{~mm})$ where $\mathrm{p}=<0.001$. The mean width of the foramen magnum was also significantly larger in males $(30.0 \pm 1.9 \mathrm{~mm})$ than in females $(27.1 \pm$ $2.4 \mathrm{~mm}$ ) where $\mathrm{p} \leq 0.001$.

Although the length and the width of the foramen magnum in males were significantly longer than females, yet there was no significant difference between males and females concerning this length-breadth index or FMI where $\mathrm{P}=0.080$. (Table 3 )

Table (4) demonstrates that FMA was significantly lower in females $\left(699.90 \pm 92.09 \mathrm{~mm}^{2}\right)$ compared to males $\left(833.50 \pm 72.52 \mathrm{~mm}^{2}\right)$ where $\mathrm{P} \leq 0.001$.

Table (5) depicts that the mean length of the maximum bicondylar distance in males was $48.8 \pm$ $2.3 \mathrm{~mm}$ while in females it was $46.1 \pm 2.2 \mathrm{~mm}$. There was a significant difference between both sexes regarding MBD where $p \leq 0.001$.

It also elucidates that the mean length of the minimum intercondylar distance was significantly longer in males $(17.2 \pm 1.7 \mathrm{~mm})$ than in females $(16.2 \pm 1.8 \mathrm{~mm})$ where $\mathrm{p} \leq 0.004$.

Table (5)compares between males and females as regards the maximum medial intercondylar distance in which the mean lengths of the maximum medial intercondylar distance was significantly longer in males $(25.1 \pm 2.4 \mathrm{~mm})$ than in females $(22.7 \pm 1.7 \mathrm{~mm})$ where $\mathrm{p} \leq 0.001$.

Table (6) revealed that in males, the length of the right condyle ranged from $20-28 \mathrm{~mm}$ with a mean of $24.8 \pm 1.7 \mathrm{~mm}$, while in females it ranged from $15-29 \mathrm{~mm}$ with a mean of $22.7 \pm 2.2 \mathrm{~mm}$. Also, the width of the right condyle in males ranged from 11-17 mm with a mean of $14.4 \pm 1.3 \mathrm{~mm}$ whereas in females it ranged from $11-16 \mathrm{~mm}$ with a mean of $13.5 \pm 1.3 \mathrm{~mm}$. The present work showed a significant difference between both sexes regarding the length and width of the right condyle where $p \leq 0.001$ and $\mathrm{p} \leq 0.001$ respectively.

Table (7) demonstrates that the mean length of the left condyle was significantly longer in males $(24.7 \pm$ $1.7 \mathrm{~mm})$ than in females $(23.4 \pm 1.8 \mathrm{~mm})$ where $\mathrm{p} \geq 0.013$, but no significant difference was noticed between the width of the right and left condyles between males and females $(p \geq 0.059)$.Moreover there was no significant difference between the width of the right and left condyles within the same sex where $\mathrm{t}=0.614$ and $\mathrm{p}=0.542$ in males and $\mathrm{t}=1.355$ and $\mathrm{p}=0.182$ in females (Table 8).

Table (9) illustrates that although the mean right and left condylar indices were slightly higher in males than in females yet no significant difference was elicited ( $\mathrm{P}=0.337$ and 0.864 respectively).

Table (10) demonstrates that among all the measured dimensions of the foramen magnum and occipital condyles in the studied Egyptian population sample, the width of the foramen magnum had the highest discriminating index with $85.6 \%$ accuracy, followed by the length of the foramen magnum (82.1\%). The width of the left condyle was the parameter that had the least discriminating index $(58.2 \%)$.

Table (11) represents six significant regression equations that were obtained for predicting sex using of the studied measurements of the foramen magnum and both condyles as independent variables and sex as dependent one.

Linear regression analysis was applied for predicting sex using the length of right condyle (LRC), length left condyle (LLC) and length of foramen magnum (LFM). The equation was significant $(p \leq 0.001)$ with accuracy $87.0 \%$. Males were predicted if value of the equation is $\geq 0.45$ (Equation 1 ).

Also linear regression analysis was applied for predicting sex using width of the right condyle (WRC), width of the left condyle(WLC) and width of the foramen magnum (WFM). The equation was significant $\left(\mathrm{R}^{2}=0.417\right.$ and $\left.\mathrm{p} \leq 0.001\right)$ with accuracy $86.0 \%$. Males were predicted if value of the equation is $\geq 0.58$ (Equation 2).

Multiple regression analysis was applied for predicting sex using all the measured parameters of the foramen magnum and occipital condyles [length of foramen magnum (LFM), width of foramen magnum (WFM), maximum bicondylar distance (MBD) , maximum medial intercondylar distance (MID), length of right condyle (LRC), width of right condyle (WRC), Length of left condyle (LLC), Width of left condyle (WLC) and minimum intercondylar distance (MnID) ]. The equation was significant $\left(R^{2}=0.469\right.$ and $\left.p<0.001\right)$ with accuracy $86 \%$. Males were predicted if value of the equation is $\geq 0.41$ (Equation 3).

Linear regression analysis was also used to predict sex from [length of foramen magnum (LFM), width of foramen magnum (WFM), maximum bicondylar distance (MBD), maximum medial intercondylar distance (MID) and minimum intercondylar distance (MnID). The equation was significant $\left(\mathrm{R}^{2}=0.453\right.$ and $\left.\mathrm{p}<0.001\right)$ with accuracy $85 \%$. Males were predicted if value of the equation is $\geq 0.48$ (Equation 4).

Equation 5 was imitative from the length and width of the foramen magnum (LFM and WFM) . The equation was significant $\left(\mathrm{R}^{2}=0.378\right.$ and $\left.\mathrm{p}<0.001\right)$ with accuracy $84 \%$. Males were predicted if value of the equation is $\geq 0.59$.

Another equation was derived from length of right condyle (LRC), width of right condyle (WRC) and width of foramen magnum (WFM)] .The equation was significant $\left(\mathrm{R}^{2}=0.449\right.$ and $\left.\mathrm{p}<0.001\right)$ with accuracy $84 \%$. Males were predicted if value of the equation is $\geq 0.48$. 
Table (1): Distribution of male and female patients according to their age and sex (n=100)

\begin{tabular}{|c|c|c|c|c|c|c|}
\hline \multirow{3}{*}{ Age } & \multicolumn{6}{|c|}{ Sex } \\
\hline & \multicolumn{2}{|c|}{$\begin{array}{c}\text { Male } \\
(n=55)\end{array}$} & \multicolumn{2}{|c|}{$\begin{array}{l}\text { Female } \\
(n=45)\end{array}$} & \multicolumn{2}{|c|}{$\begin{array}{c}\text { Total } \\
(n=100)\end{array}$} \\
\hline & No. & $\%$ & No. & $\%$ & No. & $\%$ \\
\hline $18-$ & 28 & 50.9 & 12 & 26.7 & 40 & 40.0 \\
\hline $30-$ & 16 & 29.1 & 8 & 17.8 & 24 & 24.0 \\
\hline $40-$ & 8 & 14.5 & 9 & 20.0 & 17 & 17.0 \\
\hline $50-60$ & 3 & 5.5 & 16 & 35.6 & 19 & 19.0 \\
\hline Min. - Max. & \multicolumn{2}{|c|}{$19.0-56.0$} & \multicolumn{2}{|c|}{$18.0-60.0$} & \multicolumn{2}{|c|}{$18.0-60.0$} \\
\hline Mean \pm SD & \multicolumn{2}{|c|}{$31.58 \pm 9.03$} & \multicolumn{2}{|c|}{$40.93 \pm 13.40$} & \multicolumn{2}{|c|}{$35.79 \pm 12.09$} \\
\hline $\mathbf{t}$ & \multicolumn{6}{|c|}{3.997} \\
\hline $\mathbf{p}$ & \multicolumn{6}{|c|}{$0.001^{*}$} \\
\hline
\end{tabular}

Min: Minimum; Max: Maximum; SD: standard deviation; $t$ :

Student t-test; *significance at $p \leq 0.05$

Table (2): Student t-test of the length and the width of the foramen magnum (in mm) measured on 3DMSCT in both $\operatorname{sexes}(\mathbf{n}=100)$

\begin{tabular}{|c|c|c|c|}
\hline & $\begin{array}{l}\text { Males } \\
(n=55)\end{array}$ & $\begin{array}{c}\text { Females } \\
(n=45)\end{array}$ & $\begin{array}{c}\text { Total } \\
(\mathbf{n}=\mathbf{1 0 0})\end{array}$ \\
\hline \multicolumn{4}{|l|}{ LFM (mm) } \\
\hline Min. - Max. & $31.0-40.0$ & $22.0-37.0$ & $22.0-40.0$ \\
\hline Mean \pm SD. & $35.3 \pm 1.90$ & $30.28 \pm 0.25$ & $34.2 \pm 2.5$ \\
\hline $\mathbf{t}$ & \multicolumn{2}{|c|}{5.801} & \\
\hline p & \multicolumn{2}{|c|}{$<0.001^{*}$} & \\
\hline \multicolumn{4}{|l|}{ WFM(mm) } \\
\hline Min. - Max. & $25.0-34.0$ & $16.0-32.0$ & $16.0-34.0$ \\
\hline Mean \pm SD. & $30.0 \pm 1.9$ & $27.1 \pm 2.4$ & $28.7 \pm 2.6$ \\
\hline $\mathbf{t}$ & \multicolumn{2}{|c|}{6.877} & \\
\hline p & \multicolumn{2}{|c|}{$<0.001^{*}$} & \\
\hline
\end{tabular}

LFM= length of the foramen magnum; WFM= width of the foramen magnum; Min: Minimum; Max: Maximum; $S D$ : standard deviation; $t$ : Student t-test; *significance at $p \leq 0.05$

Table (3): Comparison between males and females according to the foramen magnum index using student's t-test $(\mathbf{n}=\mathbf{1 0 0})$

\begin{tabular}{|l|c|c|c|}
\hline Foramen magnum index & $\begin{array}{c}\text { Males } \\
(\mathbf{n = 5 5})\end{array}$ & $\begin{array}{c}\text { Females } \\
(\mathbf{n = 4 5})\end{array}$ & $\begin{array}{c}\text { Total } \\
(\mathbf{n = 1 0 0})\end{array}$ \\
\hline Min. - Max. & $0.97-1.40$ & $1.08-1.44$ & $0.97-1.44$ \\
\hline Mean \pm SD. & $1.18 \pm 0.10$ & $1.21 \pm 0.09$ & $1.20 \pm 0.10$ \\
\hline t & \multicolumn{2}{|c|}{1.770} & \\
\hline p & \multicolumn{2}{|c|}{0.080} & \\
\hline
\end{tabular}

Min: Minimum; Max: Maximum; SD: standard deviation; $t$ : Student t-test; *significance at $p \leq 0.05$

Table (4): Comparison between males and females according to foramen magnum area (in mm2)using student's ttest $(\mathbf{n}=100)$

\begin{tabular}{|l|c|c|}
\hline Foramen magnum area & $\begin{array}{c}\text { Males } \\
(\mathbf{n = 5 5})\end{array}$ & $\begin{array}{c}\text { Females } \\
(\mathbf{n = 4 5})\end{array}$ \\
\hline Min. - Max. & $682.0-1015.14$ & $276.57-880.0$ \\
\hline Mean \pm SD. & $833.50 \pm 72.52$ & $699.90 \pm 92.09$ \\
\hline t & \multicolumn{2}{|c|}{8.117} \\
\hline P & \multicolumn{2}{|c|}{$<0.001^{*}$} \\
\hline
\end{tabular}

Min: Minimum; Max: Maximum; SD: standard deviation; $t$ :

Student t-test; *significance at $p \leq 0.05$ 
Table (5): Statistical analysis of the maximum bicondylar distance, minimum intercondylar distance and maximum medial intercondylar distance (in mm) measured on 3DMSCT in both sexes using student $t$ - test $(n=100)$

\begin{tabular}{|c|c|c|c|}
\hline & $\begin{array}{l}\text { Males } \\
(n=55)\end{array}$ & $\begin{array}{c}\text { Females } \\
(n=45)\end{array}$ & $\begin{array}{c}\text { Total } \\
(n=100)\end{array}$ \\
\hline \multicolumn{4}{|l|}{ MBD } \\
\hline Min. - Max. & $45.0-53.0$ & $41.0-50.0$ & $41.0-53.0$ \\
\hline Mean \pm SD. & $48.8 \pm 2.3$ & $46.1 \pm 2.2$ & $47.6 \pm 2.6$ \\
\hline $\mathbf{t}$ & \multicolumn{2}{|c|}{5.965} & \\
\hline $\mathbf{P}$ & \multicolumn{2}{|c|}{$<0.001^{*}$} & \\
\hline \multicolumn{4}{|l|}{ MnID } \\
\hline Min. - Max. & $13.0-21.0$ & $12.0-20.0$ & $12.0-21.0$ \\
\hline Mean \pm SD. & $17.2 \pm 1.7$ & $16.2 \pm 1.8$ & $16.7 \pm 1.8$ \\
\hline $\mathbf{t}$ & \multicolumn{2}{|c|}{2.988} & \\
\hline $\mathbf{P}$ & \multicolumn{2}{|c|}{$0.004^{*}$} & \\
\hline \multicolumn{4}{|l|}{ MID } \\
\hline Min. - Max. & $19.0-30.0$ & $20.0-26.0$ & $19.0-30.0$ \\
\hline Mean \pm SD. & $25.1 \pm 2.4$ & $22.7 \pm 1.7$ & $24.0 \pm 2.4$ \\
\hline $\mathbf{t}$ & \multicolumn{2}{|c|}{5.752} & \\
\hline $\mathbf{P}$ & \multicolumn{2}{|c|}{$<0.001^{*}$} & \\
\hline \multicolumn{4}{|c|}{$\begin{array}{l}\text { MBD= Maximum bicondylar distance; } \text { MnID }= \\
\text { Minimum intercondylar distance; MID = Maximum } \\
\text { medial intercondylar distance; Min: Minimum; Max: } \\
\text { Maximum; SD: standard deviation, } t: \text { Student t-test; } \\
\text { *Significance at } p \leq 0.05\end{array}$} \\
\hline
\end{tabular}

Table (6): Statistical analysis of the length and the width of the right condyle (in mm) measured on 3DMSCT in both sexes using Student's t-test $(\mathbf{n}=100)$

\begin{tabular}{|c|c|c|c|}
\hline & $\begin{array}{l}\text { Males } \\
(n=55)\end{array}$ & $\begin{array}{c}\text { Females } \\
(n=45)\end{array}$ & $\begin{array}{c}\text { Total } \\
(n=100)\end{array}$ \\
\hline \multicolumn{4}{|l|}{ LRC } \\
\hline Min. - Max. & $20.0-28.0$ & $15.0-29.0$ & $15.0-29.0$ \\
\hline Mean \pm SD. & $24.8 \pm 1.7$ & $22.7 \pm 2.2$ & $23.9 \pm 2.2$ \\
\hline $\mathbf{t}$ & \multicolumn{2}{|c|}{5.480} & \\
\hline $\mathbf{P}$ & \multicolumn{2}{|c|}{$<0.001^{*}$} & \\
\hline \multicolumn{4}{|l|}{ WRC } \\
\hline Min. - Max. & $11.0-17.0$ & $11.0-16.0$ & $11.0-17.0$ \\
\hline Mean \pm SD. & $14.4 \pm 1.3$ & $13.5 \pm 1.3$ & $14.0 \pm 14.0$ \\
\hline $\mathbf{t}$ & \multicolumn{2}{|c|}{3.563} & \\
\hline $\mathbf{P}$ & \multicolumn{2}{|c|}{$0.001^{*}$} & \\
\hline
\end{tabular}

$L R C=$ Length of the right condyle; $W R C=$ Width of the right condyle; Min: Minimum; Max: Maximum; SD: standard deviation; $t$ : Student t-test; *significance at $p$ $\leq 0.05$ 
Table (7): Statistical analysis of the length and the width of the left condyle (in mm) measured on 3DMSCT in both sexes student's t-test $(\mathrm{n}=100)$

\begin{tabular}{|c|c|c|c|}
\hline & $\begin{array}{l}\text { Males } \\
(n=55)\end{array}$ & $\begin{array}{c}\text { Females } \\
(n=45)\end{array}$ & $\begin{array}{c}\text { Total } \\
(n=100)\end{array}$ \\
\hline \multicolumn{4}{|l|}{ LLC } \\
\hline Min. - Max. & $21.0-27.0$ & $20.0-27.0$ & $20.0-27.0$ \\
\hline Mean \pm SD. & $24.7 \pm 1.7$ & $23.4 \pm 1.79$ & $24.11 \pm 1.88$ \\
\hline $\mathbf{t}$ & \multicolumn{2}{|c|}{2.590} & \\
\hline $\mathbf{P}$ & \multicolumn{2}{|c|}{$0.013^{*}$} & \\
\hline \multicolumn{4}{|l|}{ WLC } \\
\hline Min. - Max. & $12.0-17.0$ & $12.0-16.0$ & $12.0-17.0$ \\
\hline Mean \pm SD. & $14.55 \pm 1.29$ & $13.82 \pm 1.15$ & $14.22 \pm 1.28$ \\
\hline $\mathbf{t}$ & \multicolumn{2}{|c|}{1.933} & \\
\hline $\mathbf{P}$ & \multicolumn{2}{|c|}{$0.059^{*}$} & \\
\hline \multicolumn{4}{|c|}{$\begin{array}{l}\text { LLC }=\text { Length of the left condyle; WLC }=\text { Width of the left } \\
\text { condyle; Min: Minimum; Max: Maximum; SD: standara } \\
\text { deviation; } t: \text { Student } t \text {-test } * \text { significance at } p \leq 0.05\end{array}$} \\
\hline
\end{tabular}

Table (8): Comparison between the length and the width of the right and left condyles (in $\mathrm{mm}$ ) in the same sex using student's t-test $(\mathbf{n}=100)$

\begin{tabular}{|c|c|c|c|c|}
\hline & LRC & LLC & WRC & WLC \\
\hline \multicolumn{5}{|l|}{ Male } \\
\hline Min. - Max. & $20.0-28.0$ & $21.0-27.0$ & $11.0-17.0$ & $12.0-17.0$ \\
\hline Mean \pm SD. & $24.8 \pm 1.7$ & $24.69 \pm 1.76$ & $14.4 \pm 1.3$ & $14.55 \pm 1.29$ \\
\hline $\mathbf{t}$ & \multicolumn{2}{|c|}{0.443} & \multicolumn{2}{|c|}{0.614} \\
\hline $\mathbf{P}$ & \multicolumn{2}{|c|}{0.660} & \multicolumn{2}{|c|}{0.542} \\
\hline \multicolumn{5}{|l|}{ Female } \\
\hline Min. - Max. & $15.0-29.0$ & $20.0-27.0$ & $11.0-16.0$ & $12.0-16.0$ \\
\hline Mean \pm SD. & $22.7 \pm 2.2$ & $23.40 \pm 1.79$ & $13.5 \pm 1.3$ & $13.82 \pm 1.15$ \\
\hline $\mathbf{t}$ & \multicolumn{2}{|c|}{1.472} & \multicolumn{2}{|c|}{1.355} \\
\hline $\mathbf{P}$ & \multicolumn{2}{|c|}{0.148} & \multicolumn{2}{|c|}{0.182} \\
\hline
\end{tabular}

$L R C=$ Length of the right condyle; $L L C=$ Length of the left condyle; $W R C=$ Width of the right condyle; $W L C=$ Width of the left condyle; Min: Minimum; Max: Maximum; SD: standard deviation; $t$ : Student t-test;

*Significance at $p \leq 0.05$

Table (9): Comparison between males and females right and left condylar indices using student's t-test (n=100)

\begin{tabular}{|c|c|c|c|}
\hline & $\begin{array}{l}\text { Males } \\
(n=55)\end{array}$ & $\begin{array}{c}\text { Females } \\
(n=45)\end{array}$ & $\begin{array}{c}\text { Total } \\
(n=100)\end{array}$ \\
\hline \multicolumn{4}{|c|}{ Right condylar index } \\
\hline Min. - Max. & $1.47-2.27$ & $1.31-2.36$ & $1.31-2.36$ \\
\hline Mean \pm SD. & $1.74 \pm 0.18$ & $1.69 \pm 0.21$ & $1.72 \pm 0.19$ \\
\hline $\mathbf{t}$ & \multicolumn{2}{|c|}{0.965} & \\
\hline $\mathbf{P}$ & \multicolumn{2}{|c|}{0.337} & \\
\hline \multicolumn{4}{|c|}{ Left condylar index } \\
\hline Min. - Max. & $1.40-2.0$ & $1.38-2.08$ & $1.38-2.08$ \\
\hline Mean \pm SD. & $1.71 \pm 0.17$ & $1.70 \pm 0.17$ & $1.71 \pm 0.17$ \\
\hline $\mathbf{t}$ & \multicolumn{2}{|c|}{0.172} & \\
\hline $\mathbf{P}$ & \multicolumn{2}{|c|}{0.864} & \\
\hline
\end{tabular}

Min: Minimum; Max: Maximum; SD: standard deviation;

$t$ : Student t-test; *significance at $p \leq 0.05$ 
Table (10): Discriminating indices of the measured parameters: LFM, WFM, LRC, WRC, MnID, MBD, MID, LLC and WLC using Student's t-test

\begin{tabular}{|l|c|c|c|}
\hline & Accuracy \% & t & p \\
\hline WFM & 85.6 & 6.877 & $<0.001^{*}$ \\
\hline LFM & 82.1 & 5.801 & $<0.001^{*}$ \\
\hline LRC & 81.0 & 5.480 & $<0.001^{*}$ \\
\hline MID & 80.1 & 5.752 & $<0.001^{*}$ \\
\hline MBD & 79.9 & 5.965 & $<0.001^{*}$ \\
\hline WRC & 70.2 & 3.563 & $0.001^{*}$ \\
\hline MnID & 69.1 & 2.988 & $0.004^{*}$ \\
\hline LLC & 66.2 & 2.590 & $0.013^{*}$ \\
\hline WLC & 58.2 & 1.933 & $0.059^{*}$ \\
\hline
\end{tabular}

$t$ : Student t-test; *significance at $p \leq 0.05$; LRC=Length of right condyle; WRC $=$ Width of right condyle; WFM= Width of foramen magnum; LFM= Length of foramen magnum; $M B D=$ Maximum bicondylar distance; $M I D=$ Maximum medial intercondylar distance; $M n I D=$ Minimum intercondylar distance; $L L C=$ Length of left condyle; WLC = Width of left condyle

Table (11): Multivariate linear regression equation predicting sex from the studied cranial measurements (in mm) in adult Egyptian

\begin{tabular}{|c|c|c|c|c|c|c|}
\hline No. & Equation & $\mathbf{R}^{2}$ & Accuracy & $\mathbf{p}$ & $\begin{array}{c}\text { Cut } \\
\text { off } \\
\text { Value }\end{array}$ & $\begin{array}{l}\text { Adjusted } \\
\qquad \mathbf{R}^{2}\end{array}$ \\
\hline I & $\mathrm{X}=0.063 * \mathrm{LRC}+0.094 * \mathrm{LLC}+0.080 * \mathrm{LFM}-5.974$ & 0.461 & $87.0 \%$ & $<0.001^{*}$ & 0.45 & 0.444 \\
\hline II & $\begin{array}{l}\mathrm{X}=0.051 * \mathrm{LFM}+0.032 * \mathrm{WFM}+0.019 * \mathrm{LRC}+ \\
0.061 * \mathrm{LLC}+0.029 * \mathrm{WRC}+0.046 * \mathrm{WLC}+0.216 * \mathrm{MnID}+ \\
0.152 * \mathrm{MBD}+0.302 * \mathrm{MID}-6.927\end{array}$ & 0.469 & $86.0 \%$ & $<0.001^{*}$ & 0.48 & 0.429 \\
\hline III & $\mathrm{X}=0.066 * \mathrm{WRC}+0.089 * \mathrm{WLC}+0.099 * \mathrm{WFM}-4.479$ & 0.417 & $86.0 \%$ & $<0.001^{*}$ & 0.58 & 0.399 \\
\hline IV & $\begin{array}{l}\mathrm{X}=0.039 * \mathrm{WFM}+0.046 * \mathrm{LFM}+0.42 * \mathrm{MBD}+0.176 * \mathrm{MnID}+ \\
0.37 * \mathrm{MID}-0.5 .315\end{array}$ & 0.453 & $85.0 \%$ & $<0.001^{*}$ & 0.48 & 0.424 \\
\hline $\mathrm{V}$ & $\mathrm{X}=0.543 * \mathrm{LFM}+0.811 *$ WFM-3.633 & 0.378 & $84.0 \%$ & $<0.001^{*}$ & 0.59 & 0.365 \\
\hline VI & $\mathrm{X}=0.472 * \mathrm{LRC}+0.397 * \mathrm{WRC}+0.379 * \mathrm{WFM}-5.224$ & 0.449 & $84.0 \%$ & $<0.001^{*}$ & 0.48 & 0.426 \\
\hline
\end{tabular}

*significance at $p \leq 0.05$; If $X>$ (cut off value) sex is male; LRC=Length of right condyle; WRC =Width of right condyle; $W F M=$ Width of foramen magnum; LFM= Length of foramen magnum; MBD= Maximum bicondylar distance; MID= Maximum medial intercondylar distance; MnID= Minimum intercondylar distance; LLC = Length of left condyle; WLC $=$ Width of left condyle

\section{Discussion}

Human identification is one of the major and most important tasks of forensic medicine (Fortes et al., 2012). Identity cannot be established by the simple measurement of a set of parameters of an individual or a body. It can only be established by matching the parameters that can be measured or seen on the individual. The finding of a specific feature or a combination of specific features that is known to be possessed by that individual alone will add considerable weight to the conclusion (Shepherd, 2003). Assessment of sex is one of the most vital determinations to make when it is necessary to establish identity from skeletal remains. Moreover, identification techniques such as facial reconstruction would be impossible if sex could not be correctly established (Iscan and Loth, 2000).

In the present study the mean age of the patients was $35.79 \pm 12.09$ years. Forty percent of the cases were 18 to less than 30 years, where $70 \%$ of them were males. In a study done in north India by Jain et al. (2013), the age of the cases ranged from 22 to 60 years, the upper limit of this age (60 years) agree with the upper limit of the age in our study.

In the present work the mean age for female patients was about nine years higher than for males $(40.93 \pm 13.40$ years and $31.58 \pm 9.03$ years respectively). There was a significant difference as 
regards age between both sexes; this could be attributed to the fact that most victims of road traffic accident (RTA) that were referred to the radio diagnosis department for routine radiological investigation were young males who were more involved in outdoor activity.

The present study revealed that the mean length and width of the foramen magnum were significantly higher in males than in females $(\mathrm{p}=<0.001)$. This coincides with Selma et al. (2005) and Uysal et al. (2005) who showed that all measurements of the foramen magnum that were performed on virtual skulls of the Turkish population were larger in males than in females.

Similarly, Uthman et al. (2012)trying to evaluate the accuracy of FM dimensions in gender determination among a sample of Iraqi adults, noted that the mean length and width of the FM using helical CT images were significantly higher in men's skulls. In an another study conducted on 100 CT scans of adult Indians, (Gopalrao et al., 2013) confirmed that significant craniometric differences exist in the FM between both sexes where the 2 dimensions were significantly greater in males than in females. This significant higher variable among males than females may be due to the fact that males tend to have significantly larger cranial bases than females (Murshed et al., 2003). Data of the current research are in accordance with those of Jain et al, (2013) in their study on North Indian population. They postulated that the mean length and width of the foramen magnum showed significant difference between males and females and they considered them as important parameters for sex determination and constitution of biological profile. Similarly, Santhosh et al. (2013) in their study in South India, clearly indicate that males display larger mean values than females for both LFM and WFM and that statistically significant sex differences were observed for both dimensions. They clarified that in case of highly fragmentary remains, where no other skeletal remains are preserved, metric analysis of the basal region of the occipital bone may provide a statistically useful indication as to the sex of an unknown skull. Günay and Altinkök (2000) revealed that the morphological differences between skulls of different genders are mainly determined by genetic factors rather than nutrition, hormones, or muscles. Thus, the determination of gender in human skulls is based on morphological differences, mainly on the size and strength of certain structures (Rösing et al., 2007), which may be characteristics of each population that are influenced by genetic, environmental, and socioeconomic factors (Saunders and Yang, 1999).
According to Enlow and Hans (2002), the large size of the FM of the male skulls compared to that of females is explained by the fact that the main neurovascular bundle such as the cervical spinal cord, vertebral arteries, nerves and meninges passing through the skull base are larger in male than females.

On the other hand, Loyal et al. (2013) evaluated the foramen magnum for sex difference among Kenyan skulls. They clarified that the dimensions of the foramen magnum showed only ethnic variation and did not show any sexual dimorphism among Kenyan Africans. Raghavendra et al. (2012) postulated that size differences and the robust nature of the human cranium are unique to each population and thought to be influenced by genetic, environmental and socio-economic factors. Singh and Talwar (2013) in an Indian sample reported that the foramen magnum width and length were larger in females than males in contrast to the present study.

Philipp et al. (2009) and Gruber et al. (2009) found that sexual dimorphism among Central European population was also not found in either the sagittal or transverse diameter of the foramen magnum.

Several authors have emphasized on the value of FM and worked on various parameters for the purpose of sex identification. The present study revealed that the mean length of the foramen magnum in males $(35.3 \pm$ 1.9) was nearly similar to that of a sample of Indian population (35.5 \pm 2.8$)$ (Routal et al., 1984) Brazilian male skulls $(36.5 \pm 2.6)$ (Suazo et al., 2009) and to the English population (35.91 \pm 2.41$)$ (Gapert et al., 2009). Meanwhile, it was lower than the Turkish $(37.2 \pm 3.43)$ (Murshed et al., 2003) and Spanish (36.2 \pm 2.60$)$ (Herrera 1987) population but it was higher than that of South Indian male skulls (34.37 \pm 2.38$)$ (Santhosh et al., 2013).

Similarly the mean LFM of the female skulls, in the present work, was found to be $30.28 \pm 0.25$ which was lower than Brazilian population (35.6 \pm 2.5$)$ (Suazo et al., 2009), Turkish (34.6 \pm 3.16$)$ (Murshed et al., 2003), Spanish (34.30 \pm 2.04$) \quad$ (Herrera 1987), English populations (34.71 \pm 1.91$)$ (Gapert et al., 2009), South Indian population (33.80 \pm 2.56 ) (Santhosh et al., 2013), and other Indian samples $(32.0 \pm 2.8)$ (Routal. et al.,1984).

Regarding the width of the foramen magnum, the mean male value of the current research $(30.0 \pm 1.9)$, was nearly similar to many other studies as that of Brazilian skulls (30.6 \pm 2.5$)$ (Suazo et al., 2009), Indians

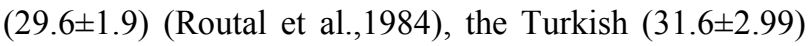
(Murshed et al., 2003), Spanish (31.1 \pm 2.60$)$ (Herrera 1987), and English population (30.51 \pm 2.60 ) (Gapert et al., 2009), but it was higher than that of the South Indian male skulls (28.98 \pm 2.22$)$ (Santhosh et al., 2013). 
In females, the mean width of the FM in this study $(27.1 \pm 2.4)$ nearly coincides with an Indian sample (27.1 \pm 1.6$)$ (Routal et al.,1984) and South Indian population (27.60 \pm 2.67$)$ ) (Santhosh et al., 2013), but it was lower than the Brazilian (29.5 \pm 1.9$)$ (Suazoet al., 2009), Turkish (29.3 \pm 2.99 ) (Murshed et al., 2003), Spanish (29.6 \pm 1.53$)$ (Herrera 1987), and English

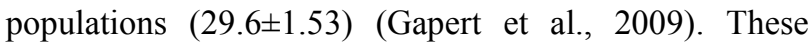
aspects can be attributed to racial differences.

The present work showed no significant difference between males and females concerning FMI where the mean FMI in males was $1.18 \pm 0.10 \mathrm{~mm}$ while that of females was $1.21 \pm 0.09 \mathrm{~mm}(\mathrm{P}=0.080)$. This finding is consistent with the study conducted by Erdil et al. (2010) on Turkish population. In this study, the FMI ranged from $0.97-1.44$ with a total mean of $1.2 \pm 0.10$. This nearly agrees with Radhika (2012) who conducted her study on 150 adult human dry skulls and found that the FMI ranged from 1.0 -1.7 with a total mean of 1.2.

The present study reported a statistically significant sex difference in the area of the FM as derived by the formula given by Radinsky (1967).It was found that FMA was higher in males than in females as $\mathrm{P} \leq 0.001$. This could be attributed to the high significant correlation of the FMA with both sagittal and transverse diameters (Murshed et al., 2003) or to the larger structure of skeletal muscle in men.

The data of the present work coincide with those of Ukoha et al. (2011) in his study in Nigeria, Gapert et al. (2008) in Britain, Murshed et al. (2003) in Turkey and Herrera (1987) in Spain. FM measurements on dry skulls done by Wanebo and Chicoine (2001) were very close to the results of the present study.

Günay and Altinkök (2000) measured the FMA directly on Turkish skulls, estimating it by considering the FM as a "circle" whose "radius" was obtained as the mean value between the half measurements of the length and the breadth. Although these values were higher than those reported in the present study; such variation may be owing to differences between the anatomic and radiographic methods.

In contrast to the present study, Singh and Talwar (2013) reported that in India, the foramen magnum area was larger in females than males. This difference may be due to their small sample size (26 males and 24 females)

In the current study, the mean lengths of the intercondylar distance: MBD, MnID, and MID were significantly longer in males than in females. This difference in the intercondylar distances reflects the asymmetry in the orientation of the occipital condyles which form the lateral limits of craniovertebral junction.
Similar results were obtained by Holland (1986) who measured the intercondylar distances on human skulls manually. Also in Turkey, Selma et al. (2005) reported that all the intercondylar distances were longer in males than females; however these differences were not statistically significant.

On the other hand, Singh and Talwar (2013) in his study done on dry skulls of an Indian population revealed that only MBD was longer in males and MnID and MID were longer in females. This may be explained by the fact that sexual dimorphism is substantially population based, due to a combination of genetic, environmental and socio-cultural factors.

In the current study the mean length and width of the right condyle and the mean length of the left condyle were significantly higher in males than in females, while the mean width of left condyle was slightly higher in males than in females but no significant difference was noticed.

This nearly agrees with Fortes et al. (2013) who studied Brazilian skulls for sex determination from occipital condylar measurements. They declared that the length and the width of both condyles were significantly higher in males than females

Holland (1986), in his study tried to estimate the sex of skeletonized individuals from the cranial bases of burnt cadavers. He reported that the measurements of the region of occipital condyles are useful for determining the sex, with an accuracy of 70-90\%.

Similarly, Selma et al. (2005) in Turkey stated that the length and width of the right condyle were statistically significant between both sexes. The length and width of the left condyle were not measured by Selma because of non-visualization by 3D CT.

On the other hand, the present study showed that there was no significant difference concerning the length and the width of the right and left condyles within the same sex. The presence of a minimal asymmetry may be due to genetic factors in some cases, or can be attributed to other different factors such as food or climatic factors (Manoel et al., 2009).

The present work showed that although the mean right and left condylar indices were slightly higher in males than in females yet no significant difference was elicited between them. Similar findings were reported by Fortes et al. (2013) who declared that there was no significant difference between both sexes regarding the condylar index. Radhika (2012) postulated that indices are also affected by the physiological and mechanical conditions that control the relations of the part concerned. Among all the measured dimensions of the foramen magnum and occipital condyles in the studied 
Egyptian population sample, the width of the foramen magnum showed the highest accuracy as a discriminating index $(85.6 \%)$. This is in accordance with Selma et al. (2005) who stated that the WFM was the most significant parameter that distinguish sex. Another study, in Brazil by Manoel et al. (2009) showed that the morphometric linear method of only the WFM was able to determine the morphological differences between sexes and can be used in conjunction with other anthropological techniques for gender determination of unknown individuals.

Discriminant function that applies to cases other than the population used to develop these functions, has known incorrect classification percentage, as sexual dimorphism is population specific.

With significant equations for sex prediction obtained by using multivariate linear regression analysis of the studied measurements of the foramen magnum and of both condyles as independent variables and sex as dependent one an accuracy ranging from $84 \%$ to $87 \%$ was obtained. To the best of our knowledge, this study was the first to investigate the relation between sex and the lengths of the foramen magnum and the inter condylar distance measured on the reconstructed 3D image of MSCT.

\section{Recommendation}

1. Modern imaging techniques are advised to gain access to forensic medicine.

2. New generations of MSCT devices should be established in the main university hospital.

3. The study of the symmetry of both condyles and its relation to age and sex is recommended.

4. Other foramina of the skull advised to be considered.

5. Further studies are needed to detect the relation between age and stature and the size of the foramen magnum.

6. Studies on the shape and size of the foramen magnum among different races is recommended.

7. Studies on a larger sample with more age groups are needed to further confirm the findings of our study. Similar studies are also proposed in other population groups.

8. Research with a larger study design and a greater number of measurable variables is advised to discriminate between male and female skulls in Egyptian population.

\section{References}

Calcagno JM (1981): On the applicability of sexing human skeletal material by discriminant function analysis. J HumEvol. 10(2):189-198.

Cardoso HFV and Saunders SR (2008): Two arch criteria of the ilium for sex determination of immature skeletal remains: a test of their accuracy and an assessment of intra- and inter- observer error. Forensic Sci Int. 178: 24-29.

Enlow DH and Hans MG (2002): Understanding facial growth, http://www.relativa.com.br/livro

Erdil FH, Sabancıoğulları V, Çimen M, et al., (2010): Morphometric analysis of the foramen magnum by computed tomography. Erciyes Med J. 32(3):167-170.

Fortes OO, Lima RTR, Daruge JE, et al., (2012): Sexual dimorphism in Brazilian human skulls: discriminant function analysis. J Forensic Odontostomatol. 30(2):26-33.

Fortes OO, Tinoco RLR, Daruge JE, et al. (2013): Sex determination from occipital condylar measurements by Baudoin index in forensic purposes. Int J Morphol. 31(4):1297-1300.

Gapert R, Black S, and Last J (2009): Sex determination from the foramen magnum: discriminant function analysis in an eighteenth and nineteenth century British sample. Int J Legal Med. 123(1):25-33.

Gopalrao SR, Solanke P, Ugale M, et al., (2013): Computed tomographic scan study of morphometry of foramen magnum. Int $\mathrm{J}$ Cur Res Rev. 5(19): 41-47.

Gruber P, Henneberg M, Böni T, et al., (2009): Variability of human foramen magnum size. Anat Rec. 292:1713-1719.

Günay Y and Altinkök M (2000): The value of the size of foramen magnum in sex determination. J Clin Forensic Med. (7):147-149.

Gunay Y, Altinkok MC, Agdir S, et al., (1997): Gender determination with skull measurements in Turkish. J Forensic Med. 13:13-19.

Herrera CJC (1987): Study of the anatomic metric values of the foramen magnum and its relation to sex. Acta Anatomica. 130:344-347.

Holland TD (1986): Sex determination of fragmentary crania by analysis of crania base. Am J Phys Anthropol. 70:203-208.

Iscan MY and Loth J (2000):Morphological estimation, In: Encyclopedia of Forensic Sciences, Seigel A, Saukko PJ and Knupper GC (eds), Academic Press, London, Sydney, pp.242-260. 
Jain SK, Choudhary AK, and Mishra P (2013): Morphometric evaluation of foramen magnum for sex determination in a documented north indian sample. J Evolut Med Dent Sci. 2(42): 8093-8098.

Kanchan T, Gupta A, and Krishan K (2013): Craniometric analysis of foramen magnum for estimation of sex. Int J Legal Med. 2:79 -83.

Kirkpatrick LA and Feeney BC (2013): A simple guide to IBM SPSS statistics for version 20.0., Wadsworth, Cengage Learning, Belmont, Calif ,pp. 115

Leslie E and Geoffrey J (1991): Statistical analysis. In: Interpretation and Uses of Medical Statistics, Leslie E, Geoffrey J, James M (eds), $4^{\text {th }}$ ed., Oxford Scientific Publications, Oxford, pp.411416.

Loyal P, Ongeti K, Pulei A, et al. (2013): Gender related patterns in the shape and dimensions of the foramen magnum in an adult Kenyan population. Anat J Afr. 2 (2): 138-141.

Manoel C, Prado FB, Caria PHF, et al., (2009): Morphometric analysis of the foramen magnum in human skulls of Brazilian individuals: its relation to gender. Braz $\mathrm{J}$ Morphol Sci. 26(2):104-108.

Murshed KA, Cicekcibasi AE, and Tuncer I (2003): Morphometric evaluation of foramen magnum. Turk J Med Sci. 33(1):301-306.

Philipp G, Henneberg M, Böni T, et al., (2009): Variability of human foramen magnum size. Anat Rec. 292:1713-1719.

Radhika PM (2012): Morphometric analysis of foramen magnum and occipital condyles in human skull. Master Thesis, Rajiv Gandhi University, Bangalore. 26-43.

Radinsky L (1967): Relative brain size a new measure. Science. 155: 836-838.

Raghavendra BYP, Kanchan T, Attiku Y, et al., (2012): Sex estimation from foramen magnum dimensions in an Indian population. J Forensic Leg Med. 19(3):162-167.

Rösing FW, Graw M, Marré B, et al., (2007): Recommendations for forensic diagnosis of sex and age from skeletons. Homo. 58:75-89.

Routal RR, Pal GP, Bhagwat SS, et al., (1984): Metrical Studies with sexual dimorphism in foramen magnum of human crania. $\mathrm{J}$ Anat Soc India. 2(33):85-89.

Sangvichien S, Boonkaew K, Chuncharunee A, et al., (2007): Sex determination in Thai skulls by using craniometry: multiple logistic regression analysis. Siriraj Med J. 59: 216-221.

Santhosh CS, Vishwanathan KG, Ashok Gupta, et al., (2013): Morphometry of the Foramen Magnum: An Important Tool in Sex Determination. Research and Reviews: Journal of Medical and Health Sciences. 4(2): 88-91.

Saunders SR and Yang D (1999): Sex determination: XX or $\mathrm{XY}$ from the human skeleton. In: Forensic Osteological Analysis, Fairgrieve SI(ed), Charles C Thomas, Springfield, pp.36-59.

Selma URM, Gokharman D, Kacar Met al., (2005): Estimation of Sex by 3D CT Measurements of the Foramen magnum. J Forensic Sci. 50:13101314.

Shepherd R (2003): Identification of the living and the dead. In: Simpson's Forensic Medicine, Shepherd R (ed), $12^{\text {th }}$ ed., Oxford University Press, London,pp49-56.

Singh G and Talwar I (2013): Morphometric analysis of foramen magnum in human skull for sex determination. Human Biol Rev. 2(2):29-41.

Suazo GIC, Russo PP, Zavando MDA, et al., (2009): Sexual dimorphism in the dimension of the foramen magnum. Int J Morphol. 27(1):21-23.

Ukoha U, Egwu OA, Okafor IJ, et al., (2011): Sexual Dimorphism in the Foramen Magnum of Nigerian Adult. Int J Biol Med Res. 2(4): 878 881.

Uthman AT, Rawi NH, and Timimi JF (2012): Evaluation of foramen magnum in gender determination using helical CT scanning. Dentomaxillofac Radiol. 41(3): 197-202.

Uysal S, Gokharman D, Kacar M, et al., (2005):Estimation of sex by 3D CT measurements of the foramen magnum. $\mathrm{J}$ Forensic Sci. 50(6):1310-1314.

Verhoff M, Ramsthaler F, Krahahn J, et al., (2008): Digital forensic osteology -possibilities in cooperation with the virtopsy project. Forensic Sci Int. 174(2-3):152-156.

Wanebo JE and Chicoine MR (2001): Quantitative analysis of the trans-condylar approach to the foramen magnum. Neurosurgery.49: 934-941.

Weber GW, Recheis W, Scholze T, et al., (1998): Virtual anthropology (VA): methodological aspects of linear and volume measurements-first results. $\begin{array}{lll}\text { Coll } & \text { Antropol. }\end{array}$ 


\section{الملخص العزبي}

\section{الاستعراف على الجنس من الثقبة العظمى في جماجم المصريين باستخدام الأشعة المقطعية ثلاثية الأبعاد}

\section{رجاء درويش' و نجلاء سلامة' و محمد الصيرفي' و وائل خليف'}

يعتبر تحديد النوع واحد من أهم و أول السمات التي يجب تقيمها في كل حالة عند الاستعراف على الإنسان لأغراض الطب الشرعي ويمكن

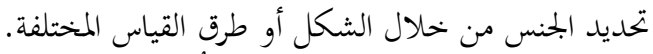

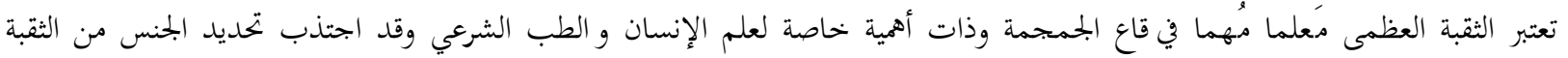

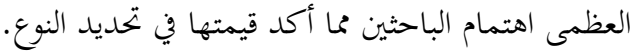

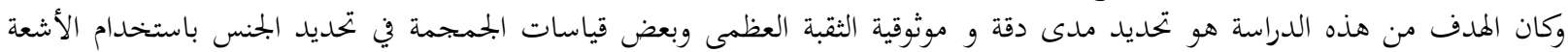
المقطعية ثلاثية الأبعاد.

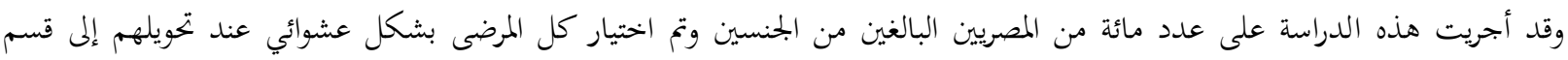

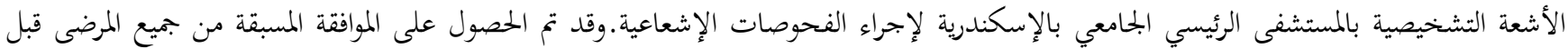

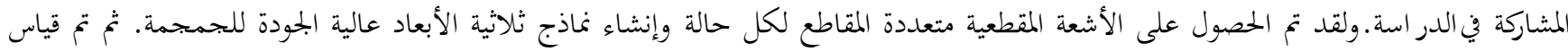

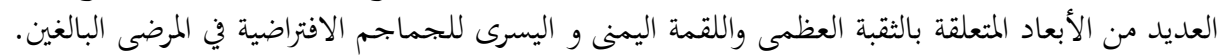

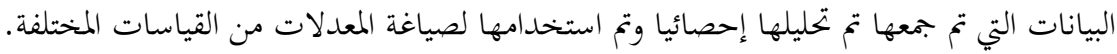

$$
\text { وقد أظهرت الدراسة النتائج الآتية: }
$$

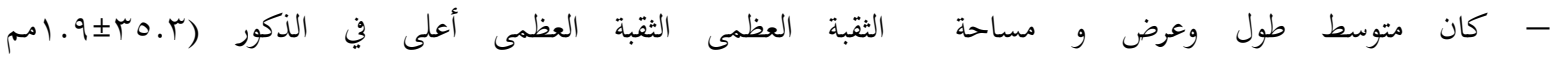

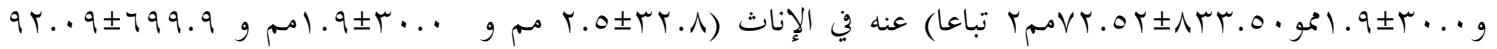

$$
\text { مشمب تباعا). }
$$

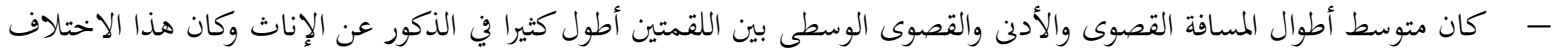

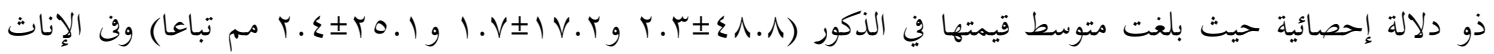

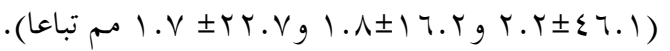

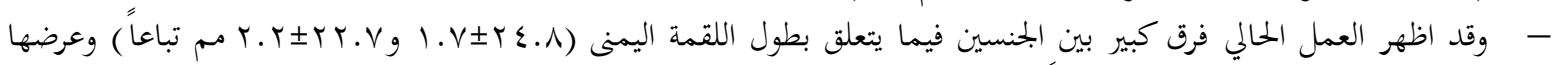

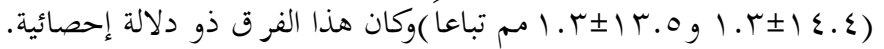

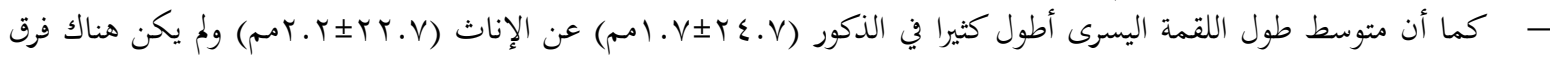

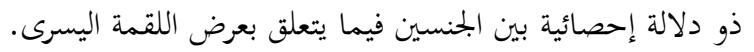

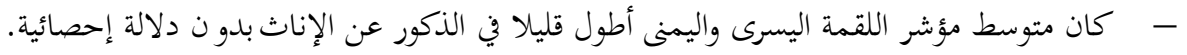

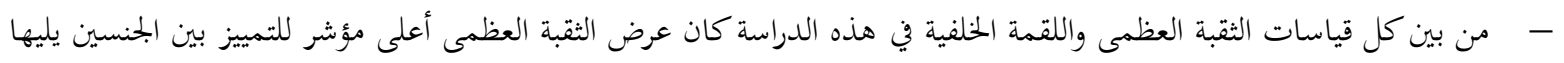

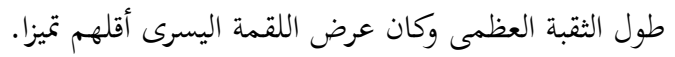

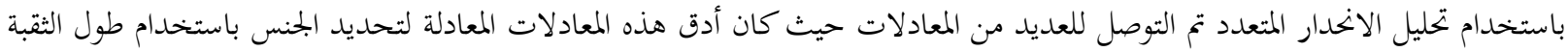

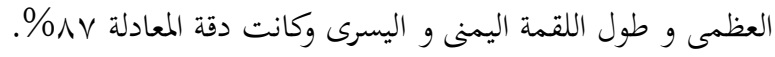
وقد أسفرت هذه الدراسة عن العديد من التوصيات من أبرزها:

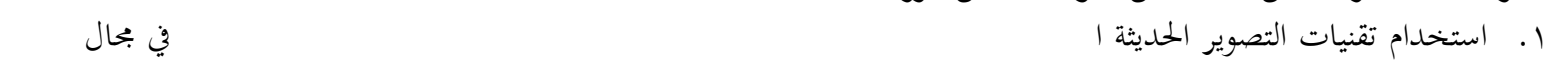

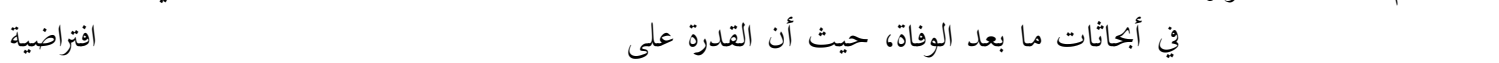
تساعدعلى حل الكثير من المشاكل الطبية الثشرية.

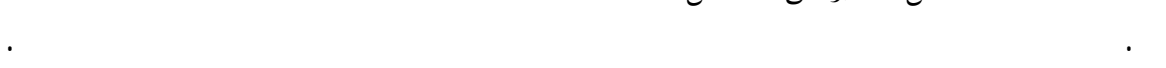
س. . هناك حاجة لإجراء دراسات على عينات أكبر عددامع مزيدمن الفئت العمرية لتأكيد تائج الدرلسة المالية.

$$
\begin{aligned}
& 1 \text { ا قسم الطب الثرعي والسموم الإكلينيكية - كلية الطب - جامعة الإسكندرية } \\
& \text { r قسم الأشعة الثتخيصية - كلية الطب - جامعة الإسكندرية }
\end{aligned}
$$

